\title{
The chronopharmacological effect of curcumin on human gall-bladder
}

\author{
Abdul Rasyid, Abdul Rashid Abdul Rahman ${ }^{* *}$, Kamaruddin Jaalam ${ }^{* *}$, Aznan Lelo ${ }^{*}$
}

\begin{abstract}
Abstrak
Secara fisiologis kandung empedu manusia berkontraksi dan mengisi kembali secara periodik. Telah dibuktikan bahwa curcumin (C) suatu bahan aktif yang terkandung didalam temulawak (curcuma xanthorrhiza) dan kunyit (curcuma domestica) mempunyai khasiat kolekinetik. Penelitian ini bertujuan untuk menentukan apakah khasiat kolekinetik kurkumin disebabkan oleh pengaruh fisiologi kontraksi dan pengisian kembali kandung empedu, dan pada jam ke berapa efek kontraksi kandung empedu maksimum setelah pemberian kurkumin $40 \mathrm{mg}$ terjadi. Penelitian dilakukan secara rawak, buta dwi pihak dan pindah silang terhadap 12 orang sukarelawan yang diberikan kurkumin $40 \mathrm{mg}$ dan plasebo $(P)$. Volume kandung empedu diukur dengan ultrasonografi menggunakan metode ellipsoid. Volume kandung empedu diukur setiap 0.5 jam selama 6 jam. Sesudah pemberian $P$ tidak dijumpai kontraksi kandung empedu. Sedangkan setelah pemberian kurkumin terjadi kontraksi selama 2 jam dan diikuti dengan fasa pengisian kembali selama 2.5 jam dan kemudian diikuti dengan kontraksi kedua yang dimulai setelah 4.5 jam sampai 6 jam. Volume maksimum kandung empedu setelah 6 jam lebih kecil daripada volume awal. Efek kolekinetik kurkumin secara kronofarmakologi tidak dipengaruhi oleh kontraksi fisiologis dan pengisian kembali kandung empedu yang terjadi secara periodik. Kurkumin memberikan efek kontraksi maksimum setelah 2 jam pemberian secara oral. (Med J Indones 2001; 10: 219-23)
\end{abstract}

\begin{abstract}
Human gallbladder physiologically contracts and relaxes periodically. It has been demonstrated that curcumin (C) an active compound of Curcuma xanthorrhiza and Curcuma domestica produces a positive cholekinetic effect. The objective of this study is to define the influence of physiologic contraction and refilling of human gallbladder on the cholekinetic effect of Curcumin, and to determine the time to achieve the maximum gall-bladder contraction after administration of $40 \mathrm{mg}$ curcumin. Twelve healthy volunteers ingested $40 \mathrm{mg} C$ and placebo $(P)$ in a randomized double blind cross over study design. The volumes of gallbladder before and after taking $C$ and $P$ were half hourly determined by uitrasonography and calculated using the ellipsoid method for 6.0 hours. After $P$ administration there is no gallbladder contraction. While after $C$ administration there was a contraction phase for 2 hours followed by a refilling phase for another 2.5 hours and then followed by second gall-bladder contraction started for 4.5 up to 6 hours. The maximal volume of gallbladder after 6.0 hours was less than the basal volume. The cholekinetic effect of $C$ is not chronopharmacologically influenced by the gall-bladder physiologic periodic contraction and refilling. The maximum contraction effect of $C$ was achieved at 2 hours after oral administraion. (Med J Indones 2001; 10: 219-23)
\end{abstract}

Keywords: curcumin, gall bladder, contraction

Medicinal plants containing curcumin as an active compound, i.e. Curcuma longa and Curcuma xanthorrihiza known as 'jamu', are traditionally used as cholagogum and also consumed for their health benefits by Indonesian people, including by pregnant women. $^{1,2}$ Human gall-biadder physiologically contracts and relaxes periodically. Our previous study demonstrated that curcumin (C) an active compound

\footnotetext{
* School of Medicine, Universitas Sumatera Utara, Medan, Indonesia

** School of Medical Sciences, Universiti Sains Malaysia, Kelantan, Malaysia
}

of Curcuma xanthorrhiza and Curcuma domestica produces a positive cholekinetic effect. Curcumin 20 $\mathrm{mg}$ is capable of contracting gall-bladder by up to $29 \%$ with the time of observation was 2 hours. ${ }^{3}$ This 2 hours time of observation was a accordance with the time of observation of the others researchers studies who observed the effect of fatty meal, ${ }^{4,5}$. Atremesia decoction. ${ }^{6}$ Further study is needed to examine the chronopharmacology effect of curcumin on human gall-bladder to define the influence of physiologic contraction and refilling of human gallbladder on the cholekinetic effect of Curcumin, and to determine the time to achieve the maximum gall-bladder contraction after administration of $40 \mathrm{mg}$ curcumin. 


\section{METHODS}

This study was conducted as randomized, double blind and cross-over design with a wash-out period of one week interval, on 12 healthy volunteers ( 7 males and 5 females) age ranging from 20 - 50 years. (Mean \pm s. d; $35,75 \pm 5.72$ years), weight ranging from 45 $65 \mathrm{~kg}(53.60 \pm 6.30 \mathrm{~kg})$ and height ranging from $150-$ $168 \mathrm{~cm}(157.50 \pm 6.20 \mathrm{~cm})$. All subjects gave informed written consent to participate the study. The study protocol was approved by the Dean of the School of Medicine, and the University Research Committee of Universitas Sumatera Utara, Medan, Indonesia. All subjects were evaluated for general good health, i.e. on the basis of medical history, physical examination, laboratory test and ultrasonography of the upper abdomen. None of them had history or clinical evidence of hepatobiliary and gastrointestinal disease or operation. None of the subjects was taking any regular medication including "jamu" and oral contraceptive pills at least 7 days before the study. All subjects were not permitted to take fatty meals before the study. They have no jaundice, and the liver and spleen were unpalpable. The bilirubine, SGOT, SGPT, alkaline phosphates, cholesterol, albumin and globulin were normal. The ultrasonography of the upper abdomen showed normal liver, gall-bladder and billiary tract. The subject who only had the ellipsoid form of gall-bladder could participate in this study.

The curcumin $\left(\mathrm{C}_{21} \mathrm{H}_{20} \mathrm{O}_{6}\right)$ used for this study were purchased from Merck Schudchardt, Munchen, Germany. The single oral dose of $40 \mathrm{mg}$ curcumin or placebo (amylum) was swallowed with $100 \mathrm{ml}$ water.

Three diameters (length, width and depth) of the gallbladder were measured by an ultrasonography to calculate its volume. An ultrasound machine used was a real time system model SSH 140 A Toshiba Japan with $3,75 \mathrm{MHz}$ convex and sector transducer similar to the one used by other investigators. 5,7

The transducer was placed in a saggital plane in the right upper quadrant of the supine subject with left lateral decubitus $45^{\circ}$ position. Each subject should hold a maximum deep thoracal inspiration for maximal visualization of gall-bladder and for standardization of the measurement of the gallbladder. The photograph of the gall-bladder was taken if the greatest size of the gall-bladder was obtained.
The image was frozen on the oscilloscope screen, the greatest length of the gall-bladder was measured on the screen with previously standardized electronic caliper. The transducer was then rotated 90 degrees to obtain the image of the short axis of the gall-bladder with the greatest transverse (width) and anteroposterior (depth) dimensions.

After an overnight fast, the length, width and depth of gall-bladder were serially measured at $7.00 \mathrm{AM}$ (as zero time) and then at $0.5,1.0,1.5,2.0,2.5,3.0,3.5$, $4.0,4.5,5.0,5.5$ and 6.0 hours after taking curcumin or placebo. The gall-bladder volume $(\mathrm{GV}, \mathrm{ml})$ was calculated with an ellipsoid method. ${ }^{7,8}$

$$
\mathrm{GV}=0,52 \mathrm{x} \text { length } \mathrm{x} \text { width } \mathrm{x} \text { depth }
$$

To express the gall-bladder contraction, it was recorded the percentage of the reduction in gallbladder volume (\% GV) compared to the fasting gallbladder volume $\left(\mathrm{GV}_{0.0}\right)$.

$$
\% \mathrm{GV}=\left[\left(\mathrm{GV}_{0.0}-\mathrm{GVt}\right) / \mathrm{GV}_{0.0}\right] \times 100 \%
$$

Where $\mathrm{GV}_{0.0}$ = fasting gall-bladder volume and GVt $=$ gall-bladder volume at the time measured. If the reduction of the gall-bladder was observed it was noted as positive contraction and vice versa.

Data obtained was expressed as mean \pm standard deviation, and statistically analyzed by analysis of variance (ANOVA) with $\mathrm{P}$ values $<0.05$ regarded as the level of statistical significant.

\section{RESULTS}

The fasting gall-bladder volumes before taking $40 \mathrm{mg}$ curcumin $(15.97 \pm 3.85 \mathrm{ml})$ and placebo $(15.83 \pm$ $3.72 \mathrm{ml})$ were not statistically difference $(\mathrm{P}>0.50)$ (table 1). The gall-bladder volume was reduced with the time interval following curcumin administration, the opposite took place in the placebo group. However, a significant different $(P<0,05)$ in the gallbladder volume between the group of curcumin and placebo appeared after 1.5 hour drug administration (Table 1 and Figure 1).

Correspondingly, $0.5,1.0,1.5,2.0,2.5,3.0,3.5,4.0$, $4.5,5.0,5.5$ and 6.0 hours after $40 \mathrm{mg}$ curcumin administration there was markedly increased of the gall-bladder contraction. This was known by the 
percentage of gall-bladder volume reduction, i.e. 8.83 $\pm 5.20,15.71 \pm 8.07,31.97 \pm 3.36$ and $50.50 \pm 3.29$ $\%$, respectively, $(\mathrm{P}<0,01)$. After that from 2.5 to 4.5 hours there was refilling and from 4.5 to 6.0 hours there was gall-bladder emptying. It is clearly seen that the gall-bladder volume after 4.5 hours $(14.33 \mathrm{ml})$ and 6.0 hours $(11.90 \mathrm{ml})$ curcumin administration were still less than the fasting gall-bladder volume (baseline) $15.97 \mathrm{ml}$. From the figure 1 it was noticed that there was a biphasic contraction after administration of $40 \mathrm{mg}$ curcumin. And the figure showed that there were 2 contraction cycle i.e. the first cycle was began at 0.5 hour up to 4.5 hours and the second cycle started from 4.5 to 6.0 hours administration of curcumin. On the other hand after placebo administration the percentage reduction of gall-bladder volume was only noticed at 1.0 hour administration by $2.06 \pm 1.0 \%$ and then after 1.0 hour placebo administration there was a negative gallbladder contraction up to 2.5 hours and then there was a gall-bladder contraction started from 2.5 hours up to
4.5 hours and then followed by a negative gall-bladder contraction up to 5.0 hours and then there was a gallbladder contraction again up to 6.0 hours. At the end of time observation ( 6 hours) the gall-bladder volume $(16.48 \pm 4.02)$ bigger compare to the baseline gallbladder volume $(15.83 \pm 3.72 \mathrm{ml})$ but was not statistically different $(\mathrm{P}<0.05$ ANOVA). Placebo followed the periodic physiologic contraction and refilling but after administration of $40 \mathrm{mg}$ curcumin there was markedly gall-bladder contraction.

From the figure 1 it is known that the maximum gallbladder contraction was seen at 2.0 hours. After administration of $40 \mathrm{mg}$ curcumin it was $50 \%$. The half of the maximum effect of curcumin (25\%) was noticed at 4.0 hours after curcumin administration. Therefore the biological half life of the curcumin was 4-2 = 2 hours (Figure 1).

During the study conducted and the day after there was no side effect reported by the subject participated.

Table 1. Gall-bladder volume after placebo and $40 \mathrm{mg}$ curcumin administration

\begin{tabular}{|c|c|c|c|c|c|c|c|c|c|c|c|c|c|c|}
\hline \multirow[t]{2}{*}{ Group } & \multicolumn{13}{|c|}{ Gall-bladder volume (ml) at the time (h) point } & \multirow[t]{2}{*}{$\mathbf{P}$} \\
\hline & 0.0 & 0.5 & 1.0 & 1.5 & 2.0 & 2.5 & 3.0 & 3.5 & 4.0 & 4.5 & 5.0 & 5.5 & 6.0 & \\
\hline \multirow[t]{2}{*}{ Placebo } & 15.83 & 15.51 & 15.16 & 15.55 & 17.26 & 17.16 & 16.78 & 16.98 & 16.92 & 16.93 & 17.25 & 17.23 & 16.48 & \multirow[t]{2}{*}{$>0.50$} \\
\hline & \pm 3.71 & \pm 3.66 & \pm 3.62 & \pm 3.70 & \pm 3.96 & \pm 3.90 & \pm 3.80 & \pm 3.93 & \pm 3.84 & \pm 3.89 & \pm 3.96 & \pm 3.98 & \pm 4.02 & \\
\hline \multirow[t]{2}{*}{ Curcumin } & 15.97 & 14.56 & 13.39 & 10.87 & 7.93 & 9.08 & 9.28 & 11.22 & 11.96 & 14.33 & 13.56 & 13.02 & 11.90 & \multirow[t]{2}{*}{$<0.01$} \\
\hline & \pm 3.84 & \pm 3.56 & \pm 2.99 & \pm 2.66 & \pm 2.13 & \pm 2.38 & \pm 2.11 & \pm 2.80 & \pm 2.98 & \pm 3.49 & \pm 3.26 & \pm 3.02 & \pm 2.80 & \\
\hline $\mathrm{P}$ & NS & NS & $<0.05$ & $<0.01$ & $<0.01$ & $<0.01$ & $<0.01$ & $<0.01$ & $<0.01$ & $<0.01$ & $<0.01$ & $<0.01$ & $<0.01$ & \\
\hline
\end{tabular}

NS = Non Significant.

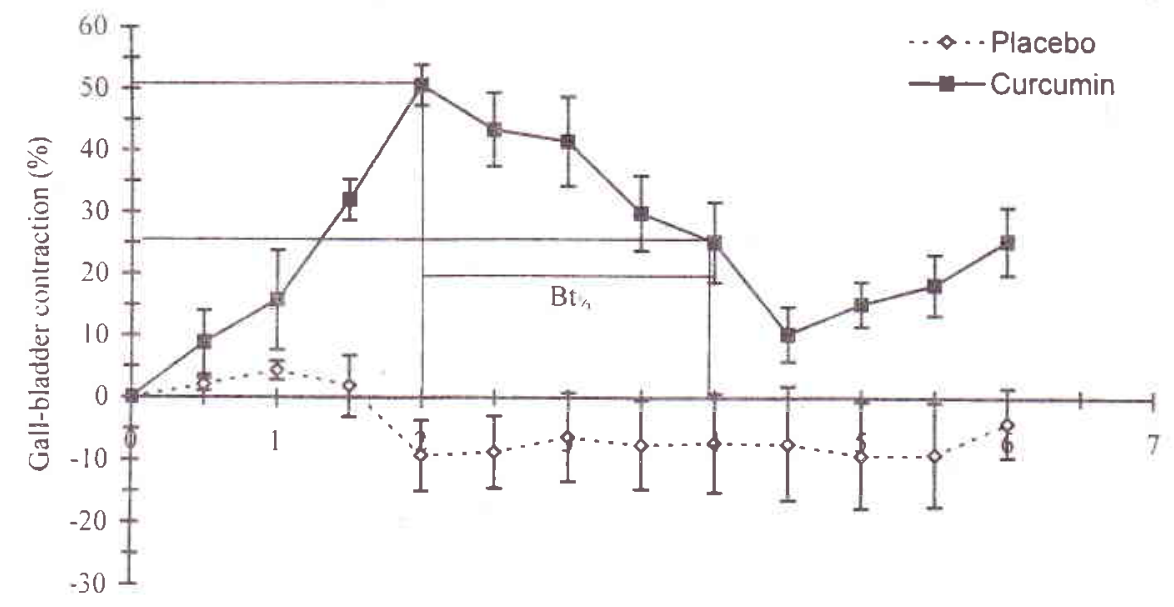

Time(hour)

Figure 1. Determination of the biological half life of the curcumin on contracting gall-bladder after administration of 40 mg curcumin. 


\section{DISCUSSION}

The fasting gall-bladder volume $\left(\begin{array}{lll} \pm & 15 & \mathrm{ml}\end{array}\right)$ demonstrated in the present study is in the range values reported by Everson et al $(16.7 \pm 2.5 \mathrm{ml})$. This double-blind placebo-controlled crossover study showed that a single oral dose of $40 \mathrm{mg}$ curcumin does stimulate the contraction of human gall-bladder. The gall-bladder volume was reduced with the time interval following curcumin administration, the opposite took place in the placebo group (figure 1). Due to the refilling physiological effect, after one hour placebo administration there was a tendency of increment of the gall-bladder volume and bigger than the fasting gall-bladder volume (baseline). On the other hand there was a steady decreased of the gallbladder volume with the time interval following curcumin administration. It was therefore a significant different $(\mathbf{P}<0,05)$ in the gall-bladder volume between the group of curcumin and placebo appeared after 1.5 hours drug administration (table 1). Correspondingly, $0.5,1.0,1.5,2.0,2.5,3.0,3.5,4.0,4.5,5.0,5.5$ and 6.0 hours after $40 \mathrm{mg}$ curcumin administration there was markedly increased of the gall-bladder contraction. This was known by the percentage of gall bladder volume reduction, i.e. $8.83 \pm 5.20,15.71 \pm 8.07,31.97$ \pm 3.36 and $50.50 \pm 3.29 \%$, respectively, $(\mathrm{P}<0,01)$. After that from 2.5 to 4.5 hours there was refilling and from 4.5 to 6.0 hours there was gall-bladder emptying. It is clearly seen that the gall-bladder volume after 4.5 hours $(14.33 \mathrm{ml})$ and 6.0 hours $(11.90 \mathrm{ml})$ curcumin administration were still less than the fasting gallbladder volume (baseline) $15.97 \mathrm{ml}$. From the (figure 1) it was noticed that there was a biphasic contraction after administration of $40 \mathrm{mg}$ curcumin. And the figure showed that there was 2 contraction cycle i.e. the first cycle began at 0.5 hour up to 4.5 hours and the second cycle started from 4.5 to 6.0 hours after administration of curcumin. On the other hand after placebo administration the percentage reduction of 40 mg gall-bladder volume was only noticed at 1.0 hour administration by $2.06 \pm 1.0 \%$ and then after 1.0 hour placebo administration there was a negative gallbladder contraction up to 2.5 hours and then there was a gall-bladder contraction started from 2.5 hours up to 4.5 hours and then followed by a negative gall-bladder contraction up to 5.0 hours and then there was a gallbladder contraction again up to 6.0 hours. At the end of time observation (6 hours) the gall-bladder volume $(16.48 \pm 4.02)$ was bigger compare to the baseline gall-bladder volume but was not statistically different
( $\mathrm{P}<0.05$ ANOVA). Curcumin $40 \mathrm{mg}$ and placebo showed different effect within the 6 hours time observation. Placebo followed the periodic physiologic contraction and refilling but after administration of 40 $\mathrm{mg}$ curcumin there was markedly gall-bladder contraction. From the figure it is known that the maximum gall-bladder contraction was seen at 2.0 hours. After administration of $40 \mathrm{mg}$ curcumin it was $50 \%$. The half of the maximum effect of curcumin $(25 \%)$ was noticed at 4.0 hours after curcumin administration. Therefore the biological half life of the curcumin was 4-2 $=2$ hours (Figure 1).

Curcumin induced a biphasic gall-bladder contraction, with maximum contractility at 2.0 hours $(50 \%)$ and between 4.5 and 6.0 hours. Erythromycin also induced a biphasic gall-bladder contraction. ${ }^{10}$

Within cholekinetic agent group erythromycine and atremesia decoction are the only two that have been studied for their chronopharmacological effect. ${ }^{6,11}$ To our knowledge this is the first study that observing the chronopharmacological effect of a cholekinetic agent curcumin with the longest observation time (6 hours) while the subject was in fasting.

\section{CONCLUSION}

The cholekinetic effect of curcumin is not chronopharmacologically influenced by the gall-bladder physiologic periodic contraction and refilling. The maximum contraction effect of curcumin was achieved at 2 hours after oral administration. The biological half life of curcumin on contracting gall-bladder after administration of $40 \mathrm{mg}$ curcumin was 2 hours.

\section{REFERENCES}

1. Agoes A, Munaf S, Lailani, Ghanie A, Aziz S. Kebiasaan minum jamu dan hubungannya dengan berat lahir (Jamu drinking habit and its relation to birth body weight). Maj Obstet Ginek Indones 1979; 5: 94.

2. Sidik. Tumbuh-tumbuhan yang berkhasiat sebagai hepatoprotektor (Plants with hepatoprotective effect). Simposium hepatitis, penanggulangan dan pemanfaatan tumbuhan obat sebagai hepatoprotektor. Bandung, 1988.

3. Rasyid A, Lelo A. The effect of curcumin and placebo on human gall-bladder function: an ultrasound study. Aliment Pharmacol Ther 1999; 13: 245. 
4. Mutirangura P, Siwawetkul W. Gallbladder contractions capacity in response to liquid fatty meal: areal ultrasonographic study. J Med Assoc Thai 1996; 79: 640.

5. Schedermaier P, Neubrand M, Hansen S, Sanerboruch T. Variability of gall-bladder emptying after oral stimulation. Scand J Gastroenterology 1997; 32: 719.

6. Zhong-Fu Y, Xian-sheng W, Combined traditional Chinese and Western medicine. Ultrasonic studies of the effect of artemisia decoction on the volume and dynamics of gallbladder. Chinese Med J 1993; 106: 145.

7. Sharma MP, Saraya A, Anand AC, Karmakar MG. Gall-bladder dysmotility in diabetes mellitus. An ultrasound study Tropical Gastroenterol 1995; 16: 13 .
8. Donald JJ, Fache SJ, Buckley RA, Burhenne JH. Gallbladder contractility: variation in normal subjects. Am J Radiol 1991; 157: 753.

9. Everson GT, Bravermann DZ, Jhonson ML, Kern F. Acritical evaluation of real time ultrasonography for the study of gallbladder volume and contraction. Gastroenterol 1980; 79: 40.

10. Kakkos SK, Yarmenitis SD, Kalfarentzos F. Gall-bladder contraction induced by intravenous erythromycin administration. Relation to body mass index. HepatoGastroenterol 1996; 43: 1540.

11. Catnach SM, Fairclough PD, Trembath RC, et al Effect of oral erythromycin on gall-bladder motility in normal subjects with gallstones. Gastroenterol 1992; 102: 2071. 